\title{
Female job satisfaction: can we explain the part-time puzzle?
}

\author{
By Sarah Bridges ${ }^{\mathrm{a}}$ and Trudy Owens ${ }^{\mathrm{b}}$
}

\author{
a School of Economics, University of Nottingham, Nottingham \\ b School of Economics, University of Nottingham, Nottingham NG7 2RD; \\ e-mail:trudy.owens@nottingham.ac.uk
}

JEL Classifications: J28 $\cdot \mathrm{J} 22 \cdot \mathrm{J} 16$

Date last accessed: 05/09/16

\begin{abstract}
Although it is generally accepted that women who work part-time are, on average, more satisfied in their jobs than their full-time counterparts, this is unlikely to be true for all women. Using the British Household Panel Survey we estimate the determinants of job satisfaction using a fixed-effects linear regression and define categories of women according to their level of education, age-cohort, family circumstances, and pathway into part-time work. We show that women who work part-time are more satisfied with their jobs, although the effect is noticeably weaker for key groups: those born in or after 1970, the better educated, and those who enter part-time employment direct from full-time work. We argue that these results reflect shifting attitudes by women towards their employment. Women today, especially those belonging to the younger cohort expect more from their jobs and are beginning to express dissatisfaction if this is not realised.
\end{abstract}




\section{Introduction}

Since the introduction of the 1970 Equal Pay Act there has been a steady narrowing in the gender pay gap in the UK for full-time working women which has been heralded as a significant development for women's equality. Although there has been a long-term downward trend in the gender pay gap for full-time employees (to around 10\% in 2013), what this hides is the lack of progress in altering the pay gap for the $42 \%$ of women who work part-time (Office of National Statistics (ONS), 2013b). Over the last four decades these women have continued to face a sizable pay penalty, in 2013 they earned only $62 \%$ of men's hourly wages. ${ }^{1}$ Despite these earnings differentials, a common finding in the job satisfaction literature is that women, on average, report higher levels of job satisfaction than men (Clark, 1997), and central to this paper, women who work part-time are more satisfied in their jobs than their full-time counterparts (Booth and van Ours, 2008; 2009).

A common explanation for this apparent paradox, especially among women who work parttime, is that the non-economic benefits of their jobs outweigh the economic rewards. Parttime employment, in particular, is seen to give women the flexibility needed for family responsibilities, implying that these women are making a lifestyle choice, although whether this choice is entirely 'free' is often subject to debate. In line with Akerlof and Kranton's (2000) gender identity hypothesis it has been argued that women are conditioned to behave in a way that is constrained by society's customs and prescribed gender roles (Booth and van Ours, 2009); gender roles that place women as the primary carers in the household thus limiting their job opportunities.

Using data from the British Household Panel Survey, a large representative data set for the United Kingdom over the period 1991 to 2009, we explore this paradox. We examine how job satisfaction is related to labour market status, chiefly part-time employment, and how satisfaction levels evolve in response to changing job expectations brought about by lifecycle events (such as having children and marriage), and changes to the UK labour market as a result of the introduction of employment legislation and the growth in Higher Education.

Building on the findings of existing studies we examine two important gaps in the literature. We look in detail at satisfaction levels among part-time workers, and examine the extent to

\footnotetext{
${ }^{1}$ In April 2013 median gross hourly earnings for men were $£ 13.60$ and $£ 12.24$ for women; for part-time women median gross hourly wages were $£ 8.40$ (ONS, 2013b).
} 
which part-time satisfaction levels are affected by work-related variables, education and family formation. Although it is generally accepted that women who work part-time are, on average, more satisfied in their jobs than their full-time counterparts, this is unlikely to be true for all women, and we seek to identify the main drivers of this satisfaction premium. We also examine the effect that transitions between different employment states, for example, moving from full to part-time employment, have on satisfaction.

We estimate the determinants of job satisfaction using a fixed-effects linear regression and identify categories of working women according to their level of education, age-cohort, family circumstances, and their pathway into part-time employment. In line with existing studies we show that women who work part-time are more satisfied with their jobs than their full-time counterparts, although the effect is noticeably weaker for certain key groups; younger women, the better educated, those who enter part-time employment direct from fulltime work, and those who have been in part-time employment for more than a year.

Of particular note we find that the determinants of job satisfaction differ markedly for two age-cohorts; those born before 1970 and those born in or after 1970. For women in the older cohort family characteristics dominate, with little role for work-related characteristics in explaining satisfaction levels, whilst the opposite is true for those in the younger cohort. Indeed, a comparison of our findings with that of men reveals that women in the younger cohort have levels of job satisfaction more in line with men than those of older women. These findings are robust to alternative estimation techniques and potential selection effects brought about by changes in the type of women who work part-time. ${ }^{2}$

We argue that our results reflect shifting attitudes by women towards their employment. Women today, especially those belonging to the younger cohort, are more highly qualified than ever before, and are more ambitious in terms of their employment goals and aspirations than those in the older cohort. They are likely to have higher expectations about what their jobs should entail, and in line with Clark's (1997) notion of the importance of job expectations in explaining satisfaction levels are willing to express dissatisfaction in the form of lower job satisfaction if this is not realised.

\footnotetext{
${ }^{2}$ Changes in the pattern of Higher Education investment and norms of female retirement have increased the proportion of 16-22 year olds and those aged 55+ in part-time employment.
} 
Of course what we are observing could also arise due to life-cycle differences between the two age-cohorts. Women in the older cohort are more likely to have older children than their younger counterparts, which may have consequences as to how satisfied they are with their jobs. We address this issue by disaggregating the two cohorts by their relationship status (couple versus single) in order to examine the effect family structure, such as the presence of dependent children, has on satisfaction levels. We find that, regardless of relationship status, job-specific characteristics related to occupational status and salary continue to have the biggest effect on satisfaction levels for the younger cohort, which provides further evidence of shifting attitudes by women towards their employment. However, we also show that the determinants of job satisfaction change when women have children. We find that regardless of age-cohort, for women who are married or cohabiting, variables associated with occupational status and salary have a much smaller effect on satisfaction levels compared to those who are single, whilst for those in the younger cohort the premium in terms of job satisfaction associated with part-time employment is driven entirely by women with dependent children.

The remainder of this paper is organised as follows. In Section 2 we present an overview of the literature on part-time employment and job satisfaction. Section 3 introduces the data and provides some preliminary descriptive statistics. In Sections 4 to 6 we present our main empirical results together with a sensitivity analysis, and in Section 7 conclude the paper.

\section{Background and Literature}

Although female labour force participation increased from 62\% to around 70\% between 1984 and $2009,42 \%$ of women in employment work part-time compared to only $12 \%$ of men (ONS, 2013b). ${ }^{3}$ Substantial evidence also suggests that women are more likely than men to be unfairly penalised in the labour market, a situation that is often exacerbated by their parttime employment status (Trade Union Congress, 2012). It is widely documented that parttime work in the UK is disproportionately concentrated in low reward, low status jobs that do not confer the same security or benefits as full-time work (see, Johnes, 2006; Connolly and Gregory, 2008; Manning and Petrongolo, 2008).

Recent research also finds that women who switch from full to part-time work often experience a downgrade to their occupational status, which is not surprising given the low

\footnotetext{
${ }^{3}$ http://stats.oecd.org/Index.aspx? DatasetCode=LFS_SEXAGE_I_R.
} 
status nature of this work. Connolly and Gregory (2008) construct a 15-category ranking of occupations based on the average level of qualifications of workers in each occupation and show that this occupational downgrading can be sizeable, with women who switch to parttime work frequently being employed in jobs where the average qualification level is well below that of their previous full-time job. Manning and Petrongolo (2008) create a ranking based on changes in pay and observe that a high proportion of the pay penalty associated with part-time work arises because women working part-time are doing very different jobs to their full-time counterparts.

Johnes (2006) considers changes in occupational status for women after childbirth. Using the Hope-Goldthorpe ranking, a ranking devised by Goldthorpe and Hope (1974) based on a survey of the social standing of occupations, he finds that $16 \%$ of women in the year following childbirth experience a downgrading in their occupational status, while $60 \%$ see no change. This shift in status tends to occur at the top end of the occupational distribution. Those in high status occupations before childbirth are likely to trade down their occupation.

Despite the economic drawbacks to part-time employment, the populist notion echoed in the academic literature asserts that for many women part-time employment is a choice which enables them to combine participation in the labour market with home and family commitments. As such, women choose to accept the lower labour market rewards associated with this type of employment in return for the other benefits that part-time employment entails (Connolly and Gregory, 2008).

This finding is given credence by the large and growing economics literature on the determinants of various components of satisfaction and happiness, including job satisfaction. Studies in this area highlight that despite the apparent economic drawbacks associated with the nature of their employment, particularly part-time work, women often find their jobs appealing and as such report higher levels of job satisfaction than men (Clark, 1997). Consistent with this finding there is evidence that working fewer hours generally has a positive effect on job satisfaction (see, Clark et al., 1996; Sousa-Poza and Sousa-Poza, 2003; Booth and van Ours, 2008, 2013). ${ }^{4}$

In this literature a worker's utility or job satisfaction is typically modelled in terms of a relative utility framework whereby individuals get utility or satisfaction from their hours

\footnotetext{
${ }^{4}$ This result holds for both men and women.
} 
worked, person and job-specific characteristics, and how they compare relative to their peers, which amongst other things may be formed out of job expectations. See inter alia: Clark and Oswald, 1996; Clark, 1997; Hamermesh, 2001; Card et al., 2012.

Clark (1997) argues that the paradox of a woman's higher level of job satisfaction, despite the nature of her employment, rests on the presence of these comparison terms in her utility function. He argues that women will report higher levels of job satisfaction than men with the same set of objective characteristics and work values if they have lower job expectations. In support of this hypothesis, Clark (1997) finds that the gender job satisfaction differential in the UK is not present for female workers who are young, highly educated, work in maledominated workplaces or in professional or managerial positions. In other words, women with similar job expectations as men report similar levels of satisfaction.

An alternative explanation for a woman's apparent satisfaction with her job emphasises the role of social customs and conditioning. Booth and van Ours (2008) using data for the UK focus specifically on partnered women and find that although those who work part-time have higher levels of job satisfaction, this does not increase their overall level of life satisfaction. They argue that partnered women may be conditioned to like being at home irrespective of the level of human capital they have accumulated, or that women are operating within the constraints imposed by society which makes it difficult for them to combine work and family care, and as such choose to work fewer hours in order to increase their job satisfaction.

As highlighted by Booth and van Ours (2008) this ties in with Akerlof and Kranton's (2000) gender identity hypothesis, and the notion of behavioural prescriptions by gender, which discusses the importance of gender identity in influencing economic outcomes. Here the allocation of market work and work in the home is driven by gender-specific 'utility'. Akerlof and Kranton (2000) argue that violating society's prescriptions of gender identity can lead to social stress and anxiety. In this setting, by fulfilling society's expectations, women appear happier in part-time work than the objective characteristics of their employment status, namely lower pay, would predict.

Similarly, Booth and van Ours (2009) using data for Australia find further evidence that partnered women are happiest with part-time work. Using time-use data they show that there is incomplete specialization of labour (between market and house work) in partnered households. In households where the male partner does most of the market work, the female 
partner carries out the majority of the work in the home. However, in households where the female does the majority of the market work, the reverse does not hold which they argue is consistent with Akerlof and Kranton's (2000) notion of gender identity, and may suggest why women are more satisfied with part-time work.

Building on these findings we look in more detail at the job satisfaction paradox, principally among those who work part-time. We examine the extent to which female satisfaction levels have evolved over time in response to changing job expectations by comparing the determinants of job satisfaction for two very different groups of women; those born before 1970 and those born in or after 1970. At the same time we broaden the discussion on gender identity to look in detail at the effect family structure has on job satisfaction levels, especially among those who work part-time, and how this has evolved over time in response to changes in the composition of the labour market.

\section{Data and Descriptive Analysis}

The British Household Panel Survey

This paper uses data from the British Household Panel Survey (BHPS), a large general household survey in the UK conducted over the period 1991 to 2009. Adults in each household are interviewed on a range of socioeconomic topics including their education, labour market activity, health and finances. In what follows we limit our discussion to female respondents aged between 16 and 65 years who are in paid employment, yielding a sample of 45,537 person-year observations.

In each wave, the BHPS collects detailed information on the respondent's level of satisfaction with their current job. Adults in paid employment are asked to rate their satisfaction levels on a scale of 1 to 7 ( 1 being 'not satisfied at all' and 7 being 'completely satisfied') with the following elements of their job: promotion prospects, total pay, relations with supervisors, job security, ability to work on their own initiative, the actual work itself, and hours of work. They are then asked to rate their overall level of job satisfaction on the same 7-point scale.

The BHPS also collects detailed information on the respondent's work status, and hours worked. As part of the main interview each year respondents are asked to describe their current labour market status, which includes the following responses: self-employed, in paid employment (full or part-time), unemployed, retired from paid work altogether, on maternity 
leave, looking after the family or home, full-time student/at school, long-term sick or disabled, on a government training scheme, or something else. We use this information to identify full and part-time workers, and where applicable the route women take into part-time employment during the sample period.

Finally, to measure occupational status there are a number of rankings in the literature which use varying objective and subjective elements, including for instance qualifications, wage rates, job activities (see, OPCS, 1990; Sicherman and Galor, 1990; Kan and Gershuny, 2006; Connolly and Gregory, 2008; Manning and Petrongolo, 2008). The most widely used measure of social or occupational prestige is the Hope-Goldthorpe $(\mathrm{H}-\mathrm{G})$ scale which was devised to measure the 'general desirability' of occupations in which perceptions of job requirements and rewards were of main importance (Goldthorpe and Hope, 1974).

The H-G scale is highly correlated with alternative measures of occupational status and job quality (see Kan and Gershuny, 2006; Dex et al., 2007 ${ }^{5}$ ). However, it was originally based on men's occupations. In line with other gender related research on this topic we take advantage of this concern (see Jacobs, 1999 and Johnes, 2006). The H-G measure compared to other more female focussed rankings enables us to address the issue outlined by Clark (1997), namely that younger women have aspirations more in line with men than older women.

Using data from the BHPS on labour market and firm-level characteristics (including occupation, size of employer/number of employees, and managerial status) we construct a measure of occupational ranking using the $\mathrm{H}-\mathrm{G}$ social prestige classification system. Although the original $\mathrm{H}-\mathrm{G}$ scale contains 124 categories that range from 82.05 (selfemployed doctors, lawyers and accountants) to 17.52 (street vendors and jobbing gardeners) in what follows we make use of the well-established collapsed version of the H-G, comprising of 36 sub-groups (as used in Evans, 1999) to examine how job satisfaction is affected by changes in occupational status. ${ }^{6}$ This version takes into account changes in status of particular jobs since the 1970s.

\section{Descriptive Statistics}

\footnotetext{
${ }^{5}$ Correlations for women aged 33 for the H-G and Connolly-Gregory is 0.876 , Sicherman-Galor 0.876 , and the Standard Occupational Classifications (major) 0.849; for women aged 42 the correlations are 0.874, 0.879 and 0.837 , respectively.

${ }^{6}$ In calculating the H-G scale we follow the syntax outlined in Dex and Ward (2007).
} 
We begin our analysis by looking at the characteristics of full and part-time working women (Table 1). In line with existing studies we define part-time workers as those who work less than 30 hours a week (see, for example, Manning and Petrongolo, 2008).

\section{$<<$ Table 1 here $>>$}

We find that women who are in part-time employment are less likely than their full-time counterparts to have a degree, are older, and are more likely to be part of a couple. They also have more dependent children, which the BHPS defines as those under the age of 16 living in the household, especially children of primary school age. This is in line with expectations; women with children below the age of 12 are more likely to be constrained by childcare issues.

In line with the existing literature we also find that part-time workers are generally concentrated in low-paid, low status jobs - the H-G measure of occupational status is significantly lower for part-time workers than their full-time counterparts (see, Elias, 1990; Manning and Petrongolo, 2008; and Connolly and Gregory, 2008). They tend to earn less than their full-time counterparts, and are less likely to receive an annual pay increment, bonus, or to be part of a profit share scheme.

In addition, despite the economic drawbacks associated with part-time employment, and in line with the findings of other studies, we find that women who work part-time are more satisfied with their jobs and life in general (see, Booth and van Ours, 2008). Such a finding also holds if we look at the components of job satisfaction separately, namely satisfaction with pay, job security, and hours worked.

The low wage nature of part-time employment may be explained by the finding that, on average, part-time workers are less qualified than their full-time counterparts. However, this still presents economists with a puzzle as to why these workers report being more satisfied with their jobs. Exploring the level of job satisfaction by education and age-cohort in Table 2, a more nuanced story begins to emerge. We find that the more qualified the respondent the less satisfied she appears with her job regardless of her hours worked.

\section{<<Table 2 here >>}

Such a finding fits in with Clark and Oswald's (1996) notion of the importance of job expectations in explaining job satisfaction outlined in the previous section. Although the 
better educated tend to have more interesting and challenging jobs, education also raises job expectations, and hence those with an education are more likely to express dissatisfaction if this is not realised. However, while those with a university level education report being the least satisfied among the part-time workers, they are still more satisfied in their jobs than their full-time counterparts. This may reflect the greater stress associated with jobs that require higher qualifications. Oguz et al. (2013) find that those with the highest level of educational attainment report higher ratings of anxiety, relative to those of lower educational attainment. Similarly, people in managerial and professional roles compared to those in technical jobs or working in low-level supervisory posts show higher levels of anxiety (Oguz et al., 2013).

To investigate this further we split the sample into two age-cohorts: those born prior to 1970 and those born in or after 1970 (columns 2, and 3). ${ }^{7}$ Women today, especially those in the younger cohort, are more highly qualified than ever before, and thus are likely to have very different aspirations and job expectations than those in the older cohort. In 1980 just $13 \%$ of young people were in full time higher education, by 1999 this figure was 34\% (Greenaway and Haynes, 2003). Women have also benefitted from the introduction of a raft of employment laws that for many in the older cohort did not exist, or were still in their infancy, when they first entered the labour market. ${ }^{8}$

We find that women in the younger cohort generally report much lower levels of job satisfaction than those in the older cohort. For instance, the level of job satisfaction for women working part-time born before 1970 is 5.72 compared to 5.50 for their younger counterparts. In addition, we find that those in the younger cohort report more similar levels of job satisfaction whether in full or part-time employment. This is particularly true for those with a university level education where there is no longer a statistically significant difference in satisfaction levels between full and part-time working women. We argue that these differences, at least in part, reflect the effect improvements in the level of education and shifting attitudes by women towards their employment have on satisfaction levels. Younger

\footnotetext{
${ }^{7}$ Analysis began with cohorts split into 10-yearly intervals. We found that those born prior to 1970 behaved in a similar way, as did those born in or after 1970. The results for the 10-yearly intervals are available upon request. Summary statistics of the variables for the two age-cohorts are reported in Table 1A in Appendix A.

${ }^{8}$ For example, the 1970s Equal Pay Act which came into force in 1975 gave men and women equal treatment in terms of pay and conditions of employment, but it was not until 1983 that the Act was amended to include work of equal value. Similarly, although some of our older cohort would have been able to take advantage of the growing maternity provision in the UK, this only became legally enforceable following the introduction of the 1996 Employment Relations Act (and strengthened in 1999).
} 
women today expect more from their jobs, and like men, are now willing to express dissatisfaction if this is not fulfilled.

\section{Pathways into Part-time Employment and Occupational Status}

Building on existing studies we turn now to examine how job satisfaction is affected by the route women take into part-time employment and by changes to their occupational status. Although, as already mentioned, a growing number of studies have looked at occupational change as women switch between full and part-time employment (see, Connolly and Gregory, 2008) to the best of our knowledge this work has not been extended to examine the effect these changes have on job satisfaction levels.

We begin by looking at the route women take into part-time employment during the sample period, identifying the following pathways into part-time work: full-time employment, selfemployment, unemployment, maternity leave, family care, education, and other (Table 3).

\section{<<Table 3 here $>>$}

In line with Connolly and Gregory (2008) we find that a high proportion of the sample (22\%) switches into part-time employment each year, and once this transition has been made persistence in the state is high; $78 \%$ of those in part-time employment in the current period were also in part-time employment the previous year. Of those that do transit into part-time employment the majority enter from either full-time employment $(11 \%)$, or family care $(4 \%)$.

Next we examine how job satisfaction levels upon entering part-time employment are influenced by the route into this type of employment. We find that the highest level of job satisfaction immediately upon entering part-time employment is for those who enter from family care (5.72). For these women part-time employment not only provides them with a route back into the labour market, affording them a degree of financial independence, but it also provides the flexibility needed for raising a family. In contrast, those entering part-time employment from education report being the least satisfied with their part-time status (5.23), suggesting this category was hoping for full-time employment. ${ }^{9}$

Finally, we examine the extent to which job satisfaction is affected by changes in occupational status upon entering part-time employment. In line with the existing literature we find that part-time work often underutilises skill sets. We compare occupational status

\footnotetext{
9 Note, those entering full-time employment from part-time report a relatively high level of job satisfaction (5.63), which may reflect the 'relief' at being back in full-time employment.
} 
before and after entering part-time employment classifying changes to occupational status as 'no change', an 'upgrade' or a 'downgrade'. For those that enter part-time employment from unemployment or out of the labour market we use their occupational status in their last known job (where possible).

We show that although changes to occupational status are relatively rare for those that do not change employment status (i.e. full-time to full time, part-time to part-time), transitions into part-time work are more likely to be accompanied by a change in occupational status compared to those who continue in their current employment state, with a downgrade in status being more common than an upgrade. This is particularly true for those who enter parttime work direct from full-time employment where workers are significantly more likely to experience a downgrade than an upgrade to their occupational status. Connolly and Gregory (2008) using a different measure of occupational ranking report similar results.

We map these changes in occupational status onto job satisfaction and find that those who enter part-time employment after a period of time spent not in employment report similar levels of satisfaction regardless of whether they experience an occupational upgrade or downgrade compared to those whose status remains unchanged. ${ }^{10}$ In contrast, for those who are currently in part-time employment or who enter this state from full or self-employment we observe a statistically significant difference in job satisfaction between those who experience an upgrade/downgrade and those whose status remains unchanged. In line with expectations, for these workers an occupational upgrade raises satisfaction levels and vice versa.

These findings suggest that although overall those who work part-time are more satisfied in their jobs, the pathway into part-time employment is important, with those who enter direct from full-time work reporting the lowest levels of satisfaction immediately upon entering this state. These workers have the most to lose from this type of employment. They are likely to experience a reduction in their level of financial independence, and given the nature of parttime work are also likely to lose out in terms of career advancement. However, although we find that part-time employment underutilises the skills of its workers, with many women experiencing a downgrade in their occupational status upon entering this state, for those who enter part-time employment after a period of time not working, this does not translate into a reduction in job satisfaction. This provides us with an indication that for some women the

\footnotetext{
${ }^{10}$ Aside from those who enter from education.
} 
nature of the job itself is not their prime concern when evaluating their level of job satisfaction.

\section{Empirical Strategy and Results}

\section{Estimation Approach}

Next, we estimate the determinants of job satisfaction using a linear fixed-effects regression, differentiating between job-specific characteristics and family characteristics in an attempt to identify the drivers of female job satisfaction, and how they evolve over time in response to key life events. Specifically we estimate a linear regression of the form:

$J S_{i t}=\beta x_{i t}+\alpha_{i}+u_{i t}$

where $x_{i t}$ is a vector of job and family characteristics, $u_{i t}$ is a random disturbance, and $\alpha_{i}$ captures time invariant individual specific effects that are constant over time.

Controlling for individual fixed-effects enables us to capture key personality traits, and other non-cognitive aspects of behaviour such as motivation, drive and ambition that might influence responses to questions on job satisfaction. ${ }^{11}$ At the same time it also helps to avoid possible selection effects, if unobservable traits affect both job satisfaction and our set of control variables (see, Georgellis et al., 2012). It is, for example, conceivable that individuals who report high job satisfaction scores may be of a certain personality type that makes them more likely to marry and less likely to divorce. In line with other studies (see, Clark et al., 2008, and Booth and van Ours, 2008, 2009) we assume that these unobservable traits are time in-variant, and hence difference them out in the fixed-effects framework. ${ }^{12}$

In specifying a linear regression we are making the assumption that job satisfaction is a cardinal rather than an ordinal construct. In other words, we assume that the difference in job satisfaction between values of say 2 and 3 is the same as the difference in job satisfaction between values of 5 and 6 . The advantage of this approach is that the linear results are easier to interpret, while producing similar empirical results to ordinal measures of subjective wellbeing (see, Ferrer-i-Carbonell and Frijters, 2004). Clark et al. (2008) adopt a similar estimation strategy when looking at the determinants of life satisfaction. As part of the

${ }^{11}$ See, for example, Judge et al. (2002) who conduct a meta-analysis and find that traits from the five-factor model of personality (i.e., extraversion, agreeableness, conscientiousness, neuroticism, and openness) link to overall job satisfaction.

${ }^{12}$ Further support for the notion that these variables are time invariant is provided by Cobb-Clark and Schurer (2012) who find that the big-five personality traits are stable for working-age adults over a four year period. 
robustness analysis we examine whether an ordinal analysis of job satisfaction produces similar results.

\section{Main Results: Baseline Estimates}

Table 4 illustrates the results for the linear regression pooled over all observations (Panel A) and also for the fixed-effects estimator (Panel B). Results are reported for the whole sample, and then separately for the two age-cohorts. ${ }^{13}$ The explanatory variables are split into joblevel and family characteristics, although the fixed-effects linear regressions only include a sub-set of these controls since they do not include variables that are time invariant, or that change only slowly over time.

When looking at the fixed-effects results, one has to keep in mind that these estimates are identified off changes within individuals over time. As such the superior properties of the fixed-effects estimates in terms of bias have to be traded off against the potential for less precise estimates, i.e., due to higher standard errors. However, although the F-statistic at the end of Table 4 testing whether $\alpha_{i}=0$ leads us to reject the model without fixed-effects, pooling over all observations produces results that are similar in terms of their sign and level of significance to the fixed-effects estimates. ${ }^{14}$

\section{$<<$ Table 4 here $>>$}

We show that in line with the summary statistics outlined in the previous section those who work part-time are the most satisfied with their jobs; overall working part-time raises satisfaction levels by $22 \%$ (pooled results). Although in the context of the pooled regressions this finding may reflect different behavioural traits between full and part-time workers, traits workers possessed prior to entering the labour market; after exploiting the panel aspect of the data in panel B we find that this result still holds. We also show that although overall women report being more satisfied in part-time employment, this effect is smaller for the younger cohort.

For the pooled linear regressions, we also find evidence of a clear division in satisfaction levels by educational status. We find that relative to those with no formal education there is a

\footnotetext{
${ }^{13}$ An alternative approach to splitting the sample by age-cohort would have been to interact the key variables of interest with the age-cohort dummy. We choose not to adopt this approach due to the large number of interaction terms this would have created later on in the paper. All our findings are, however, robust to employing this method.

14 We could also account for unobserved effects using a random-effects linear regression. However, a comparison between the fixed and random-effects linear regression leads to a rejection of the model without fixed-effects. These results are not reported here but are available upon request.
} 
falling gradient in job satisfaction by education, and as such those with a higher level of educational attainment report lower levels of job satisfaction, the effects of which are greater for the younger cohort.

When we consider job-specific characteristics that relate to occupational status and salary, further differences emerge across the two age-cohorts. We find that while occupational status has a positive effect on satisfaction levels for both cohorts, the size of the effect is greater for the younger cohort. Similarly, although having a salary that includes an annual increment has a positive effect on satisfaction levels for both cohorts, wages themselves are only significant for the younger cohort.

Next we turn to the role of the family in explaining job satisfaction. To date most studies in economics concentrate on the job-specific determinants of female job satisfaction, focussing on the effect hours of work has on satisfaction, and avoids any detailed discussion of the role of the family. ${ }^{15}$ We address this gap and include controls for both the number of children and marital status in our baseline specification. We find that for the older cohort the number of dependent children and being married has a positive effect on satisfaction levels. In contrast, for the younger cohort these effects are insignificant (fixed-effects estimates). ${ }^{16}$ One possible explanation is that these events may, in the past, have shifted priorities away from career goals towards achieving a more fulfilling family life (see, Georgellis et al., 2012). The fact that this is clearly not the case for women in our younger cohort once again provides support for the finding that the younger cohort of women have very different career aspirations to those born before 1970 .

Taking these findings together it appears that the determinants of job satisfaction differ markedly for the two age-cohorts. For the older cohort, family characteristics, especially the presence of dependent children dominate, while for the younger cohort it is job-specific characteristics that are key. We argue that these findings provide further evidence of shifting attitudes by women towards their employment. Indeed a comparison of these results with that of men reveals that women in the younger cohort have levels of job satisfaction more in line

\footnotetext{
${ }^{15}$ Exceptions to this include Clark (1997) who controls for marital status, although the role of the family is not the focus of his paper, and Booth and van Ours $(2008,2009)$ who focus on partnered women. On a related issue, Georgellis et al. (2012) consider anticipation and adaptation in job satisfaction prior to and immediately after getting married and childbirth.

${ }^{16}$ For both age-cohorts including a set of dummy variables to control for the age of children are insignificant. These results are not reported here but are available upon request.
} 
with men than older women (Table 2A in Appendix B reports the regression results for men). ${ }^{17}$

What we are observing could also arise due to life-cycle differences between the two cohorts. For example, women in the older cohort are more likely to have school-aged children than their younger counterparts, which may have consequences as to how satisfied they are with their jobs. We investigate this further in the next sub-section when we look more closely at what drives satisfaction levels among part-time women workers.

\section{Job Satisfaction: Interaction Effects}

We begin by returning to the role of education and examine the effect the level of education has on the part-time satisfaction premium once we control for unobserved individual effects in a multivariate setting. As before we report results for the entire sample and that split by age-cohort, although from now on we focus on the fixed-effects specification only (Table 5, Panel A).

\section{$<<$ Table 5 here $>>$}

We find that in line with the descriptive statistics, for the older cohort these interaction effects have a negative effect on satisfaction levels. In other words, women with qualifications are less satisfied with their part-time status than those with no formal qualifications. As already mentioned those with no formal qualifications are likely to have lower expectations about what their jobs should entail (Clark and Oswald, 1996), making them more satisfied with part-time employment than their more educated counterparts. In contrast, for the younger cohort the level of education plays no role in determining the level of satisfaction with parttime employment. Younger women have higher expectations about their jobs regardless of their hours worked. ${ }^{18}$

\footnotetext{
${ }^{17}$ For males we find little evidence of any change in the determinants of job satisfaction over time; regardless of age-cohort, men who are better paid and with higher occupational status report higher levels of job satisfaction. Although for men in the older cohort the part-time variable is positive and significant, this part-time premium is being driven by those aged $55+$, and this variable becomes insignificant when we restrict the sample to men aged less than 55 (column 2). This finding is in line with figures from the ONS that report a growth in the proportion of older people working part-time (Penfold and Foxton, 2015).

${ }^{18}$ A potential limitation of this finding is that in some instances the negative interaction effects may be being driven by a relatively small number of individuals in a particular cell (i.e. as highlighted in the summary statistics relatively few individuals report having CSEs). To provide further support for our findings, we reestimate our fixed effect regressions but only include: 'Part-time*No formal qualification' as the interaction term. We find that those born before 1970 with no formal qualifications are more satisfied in their jobs, than those with qualifications. In contrast, for those born in or after 1970, the interaction effect is insignificant. These results are not reported here but are available upon request.
} 
Next we examine the effect job characteristics have on satisfaction levels among part-time workers by interacting the part-time dummy with the job-specific variables (Panel B). We find that job-specific characteristics play little role in explaining satisfaction levels among part-time workers. An exception to this is having a salary that includes an annual increment where the interaction effect is negative and significant for both cohorts. We argue this reflects the frustration at the lack of career progression associated with part-time employment, with many women getting 'stuck' at the top of their pay grade. ${ }^{19}$ This is in line with Kosteas's (2011) finding that promotion and the expectation of a promotion leads to increased job satisfaction.

Finally we look at the effect family structure, and notably dependent children have on job satisfaction levels. In Table 6 (Panel A) we disaggregate the two age-cohorts by their relationship status (couple versus single).

\section{$<<$ Table 6 here $>>$}

We find that, regardless of their relationship status, job-specific characteristics have the biggest effect on satisfaction levels for the younger cohort which provides additional evidence of shifting attitudes by women towards their employment. At the same time there is also evidence that for both age-cohorts, job-specific characteristics have a smaller impact on job satisfaction for married or cohabiting women compared to those that are single. This might arise because women who are married or cohabiting, especially those with young children, are likely to have concerns over different aspects of their jobs than those who are single.

Indeed, interacting the part-time variable with the number of dependent children (Panel B), we find that children play a key role in explaining satisfaction levels among part-time workers, especially for those born in or after 1970 who are part of a couple. For the younger cohort the interaction effect has a positive effect, and we argue that the satisfaction this group derives from part-time employment arises from those with dependent children. ${ }^{20}$

\footnotetext{
${ }^{19}$ In firms where you receive an annual increment, salary scales are split into grades, where your grade depends on your job. Each year workers move one point up the scale until they reach the top of their grade; progression to the next grade is through promotion. In the BHPS those at the top of their given salary scale are told to report that they receive an annual increment.

${ }^{20}$ Although for the younger cohort the interaction effect is only weakly significant with a p-value of 0.11 , the part-time dummy and the interaction effect are jointly significant with a p-value of 0.06 . In addition, for this group we observe a high correlation between part-time employment and having at least one dependent child; nearly $60 \%$ of women in the younger cohort who work part-time have at least one dependent child.
} 
For the older cohort, regardless of relationship status, we find that the main part-time dummy remains positive and significant, while the interaction effect is negative and significant. This tells us that women with dependent children in this older cohort are less satisfied with their part-time status than those without children. Although this finding is at odds with the stereotypical view that women with dependent children should be more satisfied with parttime employment than any other group, since it enables them to maintain a work-life balance, we argue that this anomaly reflects the degree of 'free' choice women with children have over how many hours they work. Those without dependent children are older than their counterparts with children (see, Table 1A), and are clearly at a different stage in their lives. They may have chosen to remain in part-time work after their children left home, or may be part of the growing trend of workers who are retiring gradually by switching to part-time employment. However, whatever their motivation for working part-time they are happy with this decision. In comparison, for older women with dependent children the decision to work part-time is not necessarily an entirely free choice, but one that is imposed upon them by society's prescribed gender roles.

In summary these results highlight that young women today no longer attach the same premium in terms of job satisfaction to working part-time than their older counterparts, and for many women satisfaction levels are the same regardless of hours worked. However, the results also show that regardless of age-cohort, a woman's attitude towards her employment changes when she has children and for those in the younger cohort the premium in terms of job satisfaction associated with part-time employment is driven by the presence of dependent children.

\section{Sensitivity Analysis}

We now subject the empirical analysis to a number of robustness tests by considering alternative ways of specifying job satisfaction and in doing so employ alternative methods of estimation. We also examine whether our findings are robust to changes in the age composition of the sample.

\section{Ordinal Job Satisfaction}

We begin by examining the extent to which our results are robust to treating job satisfaction as an ordinal rather than a cardinal construct, and re-estimate the baseline specification using a pooled ordered logit regression (Table 7, panel A). However, as highlighted in Ferrer-i- 
Carbonell and Frijters (2004) ordinal models of this kind do not lend themselves to the inclusion of controls for unobserved individual heterogeneity. Maddala (1983) shows that allowing for fixed individual effects in an ordered probit regression yields inconsistent results. Thus, in line with the literature on life satisfaction (see, Winkelmann and Winkelmann, 1998 and Clark et al., 2008) we recode job satisfaction as a binary variable and control for unobserved individual fixed-effects using a conditional fixed-effects logit (Table7, panel B). Here, we code the binary variable as 1 if job satisfaction takes the value 6 or above and 0 otherwise. Since average job satisfaction is between 5 and 6 , this is roughly equivalent to classifying respondents into those who report above - and those who report below average job satisfaction. This throws away a large amount of information and hence the standard errors rise.

\section{$<<$ Table 7 here $>>$}

We find that for both the ordered logit and fixed-effects logit the results are qualitatively similar to the linear regression results. Our main variable of interest, part-time employment, remains positive and significant in all specifications, although as before the effect is much weaker for the younger cohort. For the younger cohort job-specific characteristics, specifically earnings and sector of employment, continue to dominate, while for those born before 1970 family characteristics are key. Similar results also hold if we interact part-time employment with education, job-specific characteristics, and the number of dependent children (disaggregated by relationship status). These results are not reported here but are available upon request.

\section{Entry into the Labour Market}

The analysis is based on the sample of women aged 16 to 65 who report their current labour market status as being that of paid employment (full or part-time). As such, a potential limitation of our findings is that changes to the pattern of employment in recent years may mean that our results, especially in relation to the part-time satisfaction premium, are being driven by the job expectations of women at the upper and lower end of the age distribution.

Since the early 1990s there has been a steady growth in the proportion of women aged 50+ in the labour market (Penfold and Foxton, 2015). Looking at the split by type of employment, Penfold and Foxton (2015) find that although similar proportions are working part-time to those aged 16 and over, for those working past the state pension age, part-time workers make 
up a much larger proportion; workers are increasingly choosing to retire gradually by finding part-time work. At the same time, growing trends in the proportion of young people in higher education have delayed the age at which many young people first enter full-time employment. Figures from the ONS show that employment rates for women aged 16 to 23 were higher in the 1990s than they are today, mostly as a result of the growth in higher education (ONS, 2013a). It is conceivable that this increase in the age at which young people get their first full-time job might have also increased the proportion of women working parttime as they wait for full-time employment to become available.

We address these potential selection issues in Table 8 where we examine the extent to which the relationship between job satisfaction and part-time employment is robust to changes in the age range of the sample.

\section{$<<$ Table 8 here $>>$}

In line with this discussion we find for the older cohort $65 \%$ of those aged 60 or more work part-time, compared to the cohort average of 38\%. Similarly, from 1999 onwards there was an increase in the proportion of young people working part-time; prior to 1999 around 13\% of 16 to 23 year olds worked part-time, which increased to $19 \%$ from 1999 onwards. For the older cohort we find that the results are largely unchanged when we restrict the sample to women aged 55 or less (column 1). Similarly, we find that restricting the younger cohort to those aged 23 and over provides added support for our finding that women's attitudes toward their employment are beginning to change. As before, we find that compared to women in the older cohort, family-specific characteristics have no direct effect on satisfaction levels (column 2). In addition, for this subset of women, the part-time variable is no longer significant, although in line with the previous results interacting part-time employment with the number of dependent children yields a positive and significant result (column 3), the effects of which are stronger still for those who are married or cohabiting (column 4).

\section{Job Satisfaction: Pathways and Adaptation}

From the descriptive statistics outlined in section 3 we noted that the pathway into part-time employment has an effect on job satisfaction levels. In this final section we examine whether this result is robust to controlling for job and family characteristics in a fixed-effects framework (Table 9, Panel A). As before we estimate the linear regression for the whole 
sample and that split by age-cohort, including as a set of control variables for the different pathways women can take into part-time employment.

\section{$<<$ Table 9 here $>>$}

We find that regardless of age-cohort those who enter part-time employment direct from unemployment or family care are the most satisfied with their part-time status. For these women, part-time employment provides them with a route back into the labour market, whilst for those entering direct from family care it also affords them a degree of flexibility to combine family life with paid employment. For the older cohort the remaining pathways have a much smaller impact on satisfaction levels, and are insignificant for the younger cohort. In line with earlier findings, this provides support for the idea that for many women the high level of job satisfaction associated with part-time work is not as a result of the nature of the job itself, but rather is reflective of personal circumstances that make this type of employment attractive.

Finally, we examine the extent to which those women who enter part-time employment during the sample period adapt to their new working environment. There is a large literature in psychology on adaptation which suggests that people have a genetic 'set point' of life satisfaction (see, Lykken and Tellegen, 1996). In other words, after a shift in satisfaction brought about by a change in their environment individuals return to this neutral set point. ${ }^{21}$ Few papers consider the adaptation process with respect to job satisfaction. Hanglberger (2011) tests which working conditions allow for adaptation and which do not, and finds no adaptation to rotating shift work, little adaptation to temporary employment, but full adaptation to flexitime regulations. Similarly, Georgellis et al. (2012) consider anticipation and adaptation in job satisfaction prior to and immediately after getting married and birth of first child. They find for women in full-time employment the birth of the first child has a negative effect on overall job satisfaction, which can last for up to five years.

Building on this literature, in Table 9 (Panel B) we examine the extent to which the part-time satisfaction premium persists over time. In order to identify any adaptation effects we include a series of lag variables identifying the time spent in part-time employment. For example, the

\footnotetext{
21 This hedonic treadmill model has been used empirically to test whether certain life events affect an individuals' life satisfaction (Brickman and Campbell, 1971). Recent work on adaptation in well-being to marriage, divorce, (Lucas et al., 2003; Lucas and Clark, 2006; Zimmermann and Easterlin, 2006; Stutzer and Frey, 2006) birth of first child and income (Ferrer-i-Carbonell and van Praag, 2008) find that adaptation tends to be complete, whereas it tends to be incomplete with respect to unemployment (Lucas et al., 2004; Clark, 2006).
} 
lag variable for being in part-time employment for less than a year is identified by those who were in part-time employment in the current year, but not the previous one. Similarly, being in part-time employment for one to two years is identified by those who are currently in parttime employment, were employed part-time a year ago, but not two years ago. Clark et al. (2008) and Georgellis et al. (2012) define lags in a similar way. For the older cohort we find that although after three or more years those working part-time still report being more satisfied with their jobs than their full-time counterparts, the satisfaction premium is somewhat diminished. In contrast, for the younger cohort any premium in terms of job satisfaction that these women derive from part-time employment disappears almost immediately. Again this suggests that the younger cohort see part-time employment as a temporary state to help them combine work and children. With more than one year in parttime employment this state no longer affects their levels of job satisfaction.

\section{Conclusion}

This paper uses data from the British Household Panel Survey to explore why women who work part-time report higher levels of job satisfaction than their full-time counterparts, despite the overwhelming empirical evidence that suggests part-time employment often results in women being employed in jobs that are likely to be poorly paid, confer low status, and that do not have the same security or benefits as full-time employment.

A common explanation for this finding is that women who work part-time are making a lifestyle choice whereby part-time employment gives them the flexibility to combine paid employment with family care. Although this is undoubtedly true for some women, we find that not all women express the same level of satisfaction with their 'choice'. We find that there is a significant decline in the part-time effect among the better educated, those who enter part-time employment direct from full-time employment, and among those who have been in part-time employment for more than one year. We also show that the gap in job satisfaction between full and part-time female employees has narrowed over time. Unlike in previous generations, women born in or after 1970 have higher expectations about what their jobs should entail - more aligned to those of men - and consequently do not attach the same premium to part-time employment.

Taking these findings together it is evident that policymakers and employers need to reevaluate the nature of part-time employment in the United Kingdom. Women today are more 
qualified than ever before, and yet many are being forced into jobs that are well below their potential. Not only are women becoming increasingly dissatisfied with this type of employment, but with nearly $30 \%$ of the UK workforce in part-time employment, employers are also underutilising the skills of a sizeable part of its workforce. Although the government have gone someway to try and address this issue with the recently introduced right for all employees to request flexible work arrangements, the most universally available flexible working arrangement is still part-time hours (ONS, 2014). ${ }^{22}$

\section{Supplementary material}

Supplementary material- the Appendix and Data replication files - are available online at the OUP website.

\section{References}

Akerlof, G. and Kranton, R. (2000) Economics and Identity, The Quarterly Journal of Economics, 115, 715-753.

Booth, A. and van Ours, J. (2008) Job Satisfaction and Family Happiness: The Part-time Work Puzzle, The Economic Journal, 118, F77-F99.

Booth, A. and van Ours, J. (2009) Hours of Work and Gender Identity: Does Part-time Work Make the Family Happier?, Economica, 76(301), 176-196.

Booth, A. and van Ours, J. (2013) Part-time Jobs: What Women Want?, Journal of Population Economics, 26(1), 263-283.

Brickman, P. and Campbell, D. (1971) Hedonic Relativism and Planning the Good Society', in: M. Appley (ed.), Adaptation-level Theory - A Symposium, Academic Press, New York, 287-302.

Card, D., Mas, A., Moretti, E., and Saez, E. (2012) Inequality at Work: The Effect of Peer Salaries on Job Satisfaction, American Economic Review, 102(6), 2981-300.

Clark, A. (1997) Job Satisfaction and Gender: Why are Women so Happy at Work?, Labour Economics, 4(4), 341-372.

Clark, A. (2006) A Note on Unhappiness and Unemployment Duration, Applied Economics Quarterly, 52, 291-308.

Clark, A., Diener, E., Georgellis, Y., and Lucas, R. (2008) Lags and Leads in Life Satisfaction: A Test of the Baseline Hypothesis, The Economic Journal, 118, F222-F243.

${ }^{22}$ Adhoc figures published by the ONS in June 2014 (ONS, 2014). 
Clark, A. and Oswald, A. (1996) Satisfaction and Comparison Income, Journal of Public Economics, 61, 359-381.

Clark, A., Oswald, A., and Warr, P. (1996) Is Job Satisfaction U-shaped in Age?, Journal of Occupational and Organizational Psychology, 69, 57-81.

Connolly, S., and Gregory, M. (2008) Moving Down: Women's Part Time Work and Occupational Change in Britain 1991-2001', The Economic Journal, 118, F52-F76.

Cobb-Clark, D. and Schurer, S. (2012) The Stability of Big-five Personality Traits, Economics Letters, 115 (1), 11-15.

Dex, S. and Ward, K. (2007) Derivation of Hope-Goldthorpe Occupational Classification for NCDS Sweep 6, CLS Cohort Studies Data Note 2007/4, Centre for Longitudinal Studies, Institute of Education, London.

Dex, S., Lindley, J., and Ward, K. (2007) Vertical Occupational Mobility and its Measurement, Sheffield Economic Research Paper Series, SERP Number: 2007006, University of Sheffield, Sheffield.

Elias, P. (1990) Part-time Work and Part-time Workers: Keeping Women In or Out? in S. McRae(ed.), Keeping Woman In, Policy Studies Institute, London.

Evans, P. (1999) Occupational Downgrading and Upgrading in Britain, Economica, 66, 7996.

Ferrer-i-Carbonell, A. and Frijters, P. (2004) How Important is Methodology for the Estimates of the Determinants of Happiness? The Economic Journal, 114, 641-659.

Ferrer-i-Carbonell, A. and van Praag, B. (2008) Do People Adapt to Changing Circumstances? The Discussion is not Finished Yet, ICREA, mimeo.

Georgellis, Y., Lange, T., and Tabvuma, V. (2012) The impact of Life Events on Job Satisfaction, Journal of Vocational Behavior, 80(2), 464-473.

Greenaway, D. and Haynes, M. (2003) Funding Higher Education in the UK: The Role of Fees and Loans', The Economic Journal, 113, F150-F166.

Goldthorpe, J. and Hope, K. (1974) The Social Grading of Occupations: A New Approach and Scale, Oxford: Oxford University Press.

Hamermesh, D. S. (2001) The Changing Distribution of Job Satisfaction, Journal of Human Resources, 36(1), 1-30.

Hanglberger, D. (2011) Does Job Satisfaction Adapt to Working Conditions? An Empirical Analysis for Rotating Shift Work, Flexitime, and Temporary Employment in UK, FFB Discussion Paper No. 87.

Jacobs, S. (1999) Trends in Women's Career Patterns and in Gender Occupational Mobility in Britain, Gender, Work and Organization, 6, 32-46. 
Johnes, G. (2006) Career Interruptions and Labour Market Outcomes, EOC Working Paper Series No.45, Manchester: Equal Opportunities Commission

Judge, T. A., Heller, D., and Mount, M. K. (2002) Five-Factor model of personality and job satisfaction: A meta-analysis. Journal of Applied Psychology, 87, 530-541.

Kan, M.Y. and Gershuny, J. (2006) Human Capital and Social Position in Britain: Creating a Measure of Wage-earning Potential from BHPS Data. Institute for Social and Economic Research Working Paper 2006-03, University of Essex, Colchester.

Kosteas, V.D. (2011) Job Satisfaction and Promotions, Industrial Relations, 50, 174-194

Lucas, R. and Clark, A. (2006) Do People Really Adapt to Marriage? Journal of Happiness Studies, 7, 405-426.

Lucas, R., Clark, A., Georgellis, Y., and Diener, E. (2003) Re-examining Adaptation and the Set Point Model of Happiness: Reactions to Changes in Marital Status, Journal of Personality and Social Psychology, 84, 527-39.

Lucas, R., Clark, A., Georgellis, Y., and Diener, E. (2004) Unemployment Alters the Setpoint for Life satisfaction', Psychological Science, 15, 8-13.

Lykken D. and Tellegen, A. (1996) Happiness is a Stochastic Phenomenon, Psychological Science, 7(3), 186-189.

Maddala, G. S. (1983) Limited Dependent and Qualitative Variables in Econometrics, Cambridge, Cambridge University Press.

Manning, A. and Petrongolo, B. (2008) The Part-Time Pay Penalty for Women in Britain', The Economic Journal, 118, FF28-F51.

Oguz, S., Salah, M., and Snape, D. (2013) Measuring national well-being - what matters most to personal well-being?, Office for National Statistics, May 2013, London.

OPCS (1990) The Standard Occupational Classification Vol. 3, HMSO, Office of Population Censuses and Surveys, London.

ONS, (2013a) Women in the Labour Market, Office for National Statistics, September 2013, London.

ONS, (2013b) Annual Survey of Hours and Earnings, 2013, Statistical Bulletin, Office for National Statistics, December 2013, London.

ONS, (2014) People in employment (aged 16+) with flexible working conditions, October to December, 2010 to 2013, UK, Spreadsheet found at www.ons.gov.uk/.../flexible-working-october---december-2010---2013.xls.

Penfold, M. and Foxton, F. (2015) Participation Rates in the UK - 2014-3. Older People, Office for National Statistics, March 2015, London. 
Sicherman, N. and Galor, O. (1990) A Theory of Career Mobility, Journal of Political Economy, 98, 169-192.

Sousa-Poza, A. and Sousa-Poza, A.A. (2003) Gender Differences in Job Satisfaction in Great Britain, 1991-2000: Permanent or Transitory?, Applied Economics Letters, 10, 691-694.

Stutzer, A. and Frey, B.S. (2006) Does Marriage make People Happy, or do Happy People get Married?, Journal of Socio-Economics, 35, 326-47.

Trade Union Congress, (2012) Women's Pay and Employment Update: A Public/Private Sector Comparison, Report to the Women's Conference 2012.

Winkelmann, L. and Winkelmann, R. (1998) Why Are the Unemployed So Unhappy? Evidence from Panel Data, Economica, 65, 1-15.

Zimmermann, A. and Easterlin, R. (2006) Happily ever After? Cohabitation, Marriage, Divorce, and Happiness in Germany, Population and Development Review, 32, 511-28. 
Table 1: Summary Statistics

\begin{tabular}{|c|c|c|c|c|}
\hline \multirow[b]{2}{*}{ Variable } & \multicolumn{2}{|c|}{ Full-time } & \multicolumn{2}{|c|}{ Part-time } \\
\hline & Mean & $\begin{array}{l}\text { Std. } \\
\text { Dev. }\end{array}$ & Mean & $\begin{array}{l}\text { Std. } \\
\text { Dev. }\end{array}$ \\
\hline \multicolumn{5}{|l|}{ Job-specific Characteristics: } \\
\hline Occupational ranking (Hope-Goldthorpe scale) & 48.57 & 13.72 & 40.15 & 14.04 \\
\hline Ln(real hourly wage) & 6.83 & 4.25 & 5.56 & 5.11 \\
\hline Pay includes annual increments & 0.57 & 0.49 & 0.40 & 0.49 \\
\hline Pay includes bonuses or profit share & 0.26 & 0.44 & 0.18 & 0.39 \\
\hline Employed in the public sector & 0.43 & 0.50 & 0.43 & 0.49 \\
\hline Union or staff association at workplace & 0.57 & 0.49 & 0.48 & 0.50 \\
\hline Number of employees at workplace (1000 or more) & 0.12 & 0.33 & 0.07 & 0.26 \\
\hline \multicolumn{5}{|l|}{ Highest Academic Qualification: } \\
\hline Higher degree & 0.03 & 0.18 & 0.02 & 0.12 \\
\hline Degree & 0.16 & 0.37 & 0.09 & 0.28 \\
\hline HND or equivalent & 0.09 & 0.28 & 0.06 & 0.23 \\
\hline A-level & 0.21 & 0.41 & 0.16 & 0.37 \\
\hline GCSE/O-level & 0.31 & 0.46 & 0.34 & 0.47 \\
\hline CSE & 0.05 & 0.22 & 0.08 & 0.27 \\
\hline No formal qualifications & 0.15 & 0.35 & 0.26 & 0.44 \\
\hline \multicolumn{5}{|l|}{ Demographic Characteristics: } \\
\hline Age (years) & 37.36 & 11.51 & 41.58 & 11.02 \\
\hline Health over last 12 months 'excellent' & 0.27 & 0.45 & 0.25 & 0.43 \\
\hline Couple & 0.67 & 0.47 & 0.83 & 0.38 \\
\hline Number of dependent children & 0.44 & 0.78 & 1.05 & 1.04 \\
\hline Child between 0 and 2 & 0.03 & 0.18 & 0.09 & 0.29 \\
\hline Child between 3 and 4 & 0.04 & 0.19 & 0.11 & 0.32 \\
\hline Child between 5 and 11 & 0.14 & 0.35 & 0.36 & 0.48 \\
\hline Child between 12 and 15 & 0.14 & 0.35 & 0.23 & 0.42 \\
\hline \multicolumn{5}{|l|}{ Job Satisfaction: } \\
\hline Overall & 5.40 & 1.29 & 5.68 & 1.20 \\
\hline Total pay & 4.84 & 1.58 & 5.13 & 1.53 \\
\hline Job security & 5.47 & 1.49 & 5.59 & 1.44 \\
\hline Work itself & 5.49 & 1.32 & 5.64 & 1.30 \\
\hline Hours worked & 5.17 & 1.43 & 5.78 & 1.28 \\
\hline Life Satisfaction & 5.20 & 1.11 & 5.27 & 1.17 \\
\hline Number of Observations & & & & \\
\hline \multicolumn{5}{|c|}{$\begin{array}{l}\text { Notes: (1) A t-test for the equality of means between full and part-time workers shows that all } \\
\text { characteristics are statistically different at the 5\%, aside from 'employed in the public sector'; (2) } \\
\text { For qualification the final category is 'No formal qualifications' (from those listed). The vast } \\
\text { majority of those with no formal qualifications have no qualifications of any kind, although a } \\
\text { small proportion (less than } 15 \% \text { ) have clerical and commercial qualifications (e.g. typing and } \\
\text { shorthand), or apprenticeships; (3) Respondents are only asked about their life satisfaction from } \\
1996 \text { onwards. }\end{array}$} \\
\hline
\end{tabular}


Table 2: Job Satisfaction disaggregated by Age-Cohort and Education

\begin{tabular}{|l|cc|cc|cc|}
\hline \multirow{2}{*}{} & \multicolumn{2}{|c|}{ (1) } & \multicolumn{2}{c|}{ (2) } & (3) \\
\cline { 2 - 6 } & \multicolumn{2}{|c|}{ All } & Born before 1970 & Born in or after 1970 \\
\hline Qualification & Full-time & Part-time* & Full-time & Part-time* & Full-time & Part-time** \\
\hline Higher degree & 5.22 & 5.29 & 5.26 & 5.28 & 5.11 & 5.35 \\
Degree & 5.28 & 5.41 & 5.28 & 5.45 & 5.29 & 5.28 \\
HND or equivalent & 5.36 & 5.58 & 5.36 & 5.59 & 5.37 & 5.54 \\
A-level & 5.38 & 5.59 & 5.39 & 5.63 & 5.37 & 5.49 \\
GCSE/O-level & 5.45 & 5.70 & 5.45 & 5.73 & 5.45 & 5.56 \\
CSE & 5.50 & 5.64 & 5.52 & 5.69 & 5.46 & 5.52 \\
No formal qualifications & 5.46 & 5.87 & 5.46 & 5.88 & 5.58 & 5.65 \\
\hline Total & 5.40 & 5.68 & 5.41 & 5.72 & 5.38 & 5.50 \\
\hline Notes: * A t-test of the equality of the means between full and part-time workers shows that the level of job \\
satisfaction is statistically different at 5\%, aside from those with a Higher degree. ** A t-test of the equality of the \\
means between full and part-time workers shows that the level of job satisfaction is not statistically different at 5\% \\
aside from those with A-levels and GCSE/O-levels.
\end{tabular}

Table 3: Pathway into Part-time Employment and Occupational Status

\begin{tabular}{|c|c|c|c|c|c|c|c|c|}
\hline \multirow{3}{*}{ Pathways } & \multirow{3}{*}{$\%$} & \multirow{2}{*}{\multicolumn{3}{|c|}{ Occupation Change (\%) }} & \multicolumn{4}{|c|}{ Job Satisfaction } \\
\hline & & & & & \multirow[t]{2}{*}{ At t } & \multicolumn{3}{|c|}{ Occupation Change } \\
\hline & & $\begin{array}{c}\text { No } \\
\text { change }\end{array}$ & Upgrade & Downgrade & & $\begin{array}{c}\text { No } \\
\text { change }\end{array}$ & Upgrade & Downgrade \\
\hline Full-time to full-time & 88.25 & 71.84 & 15.21 & 12.95 & 5.37 & 5.37 & 5.39 & 5.34 \\
\hline $\begin{array}{l}\text { Part-time to part-time } \\
\text { Pathways into part-time: }\end{array}$ & 78.16 & 78.40 & 11.64 & 9.96 & 5.70 & 5.71 & $5.66^{*}$ & $5.60^{*}$ \\
\hline Full-time to part-time & 10.77 & 65.50 & 15.36 & 19.13 & 5.55 & 5.55 & $5.73 *$ & $5.40^{*}$ \\
\hline Self-employment to part-time & 0.90 & 39.17 & 28.33 & 32.50 & 5.64 & 5.96 & $5.24 *$ & $5.62 *$ \\
\hline Unemployment to part-time & 1.34 & 32.02 & 28.65 & 39.33 & 5.57 & 5.51 & 5.63 & 5.57 \\
\hline Maternity leave to part-time & 2.23 & 67.34 & 15.15 & 17.51 & 5.49 & 5.46 & 5.76 & 5.37 \\
\hline Family care to part-time & 4.35 & 43.25 & 25.78 & 30.97 & 5.72 & 5.78 & 5.68 & 5.68 \\
\hline Education to part-time & 1.32 & 59.09 & 27.27 & 13.64 & 5.23 & 4.94 & $5.65^{*}$ & $5.63^{*}$ \\
\hline Other to part-time & 0.92 & 59.02 & 13.11 & 27.87 & 5.76 & 5.64 & 6.06 & 5.88 \\
\hline Total (pathway into part-time) & 21.84 & 57.46 & 19.39 & 23.15 & 5.57 & 5.55 & 5.68 & $5.54 *$ \\
\hline
\end{tabular}


Table 4: Job Satisfaction - Base Specification

\begin{tabular}{|c|c|c|c|c|c|c|}
\hline \multirow[b]{2}{*}{ Variable } & \multicolumn{3}{|c|}{ Panel A: Pooled OLS } & \multicolumn{3}{|c|}{ Panel B: Fixed Effects } \\
\hline & All & $\begin{array}{c}\text { Born } \\
\text { before } \\
1970\end{array}$ & $\begin{array}{l}\text { Born in or } \\
\text { after } 1970\end{array}$ & All & $\begin{array}{c}\text { Born } \\
\text { before } \\
1970\end{array}$ & $\begin{array}{l}\text { Born in or } \\
\text { after } 1970\end{array}$ \\
\hline Employed part-time & $\begin{array}{c}0.224 * * * \\
(0.024)\end{array}$ & $\begin{array}{c}0.216^{* * * *} \\
(0.024)\end{array}$ & $\begin{array}{c}0.082 * * \\
(0.041)\end{array}$ & $\begin{array}{c}0.160 * * * \\
(0.021)\end{array}$ & $\begin{array}{c}0.157 * * * \\
(0.021)\end{array}$ & $\begin{array}{c}0.089 * * \\
(0.041)\end{array}$ \\
\hline Part-time*Born in or after 1970 & $\begin{array}{c}-0.120 * * * \\
(0.039)\end{array}$ & & & $\begin{array}{c}-0.086^{* *} \\
(0.041)\end{array}$ & & \\
\hline Occupational ranking (Hope-Goldthorpe scale) & $\begin{array}{c}0.002 * * \\
(0.001)\end{array}$ & $\begin{array}{c}0.000 \\
(0.001)\end{array}$ & $\begin{array}{c}0.006^{* * *} \\
(0.001)\end{array}$ & $\begin{array}{c}0.005 * * * \\
(0.001)\end{array}$ & $\begin{array}{c}0.004 * * * \\
(0.001)\end{array}$ & $\begin{array}{c}0.006^{* * * *} \\
(0.001)\end{array}$ \\
\hline Ln(real hourly wage) & $\begin{array}{c}0.003 \\
(0.003)\end{array}$ & $\begin{array}{c}0.002 \\
(0.003)\end{array}$ & $\begin{array}{c}0.017 * * * \\
(0.004)\end{array}$ & $\begin{array}{c}0.004 * * \\
(0.002)\end{array}$ & $\begin{array}{c}0.002 \\
(0.002)\end{array}$ & $\begin{array}{c}0.012 * * \\
(0.005)\end{array}$ \\
\hline Pay includes annual increments & $\begin{array}{c}0.153 * * * \\
(0.017)\end{array}$ & $\begin{array}{c}0.143 * * * \\
(0.021)\end{array}$ & $\begin{array}{c}0.161 * * * \\
(0.030)\end{array}$ & $\begin{array}{c}0.130 * * * \\
(0.014)\end{array}$ & $\begin{array}{c}0.120 * * * \\
(0.016)\end{array}$ & $\begin{array}{c}0.155^{* * *} \\
(0.029)\end{array}$ \\
\hline Employed in the public sector & $\begin{array}{c}0.177 * * * \\
(0.024)\end{array}$ & $\begin{array}{c}0.169 * * * \\
(0.029)\end{array}$ & $\begin{array}{c}0.221 * * * \\
(0.041)\end{array}$ & $\begin{array}{c}0.216^{* * *} \\
(0.023)\end{array}$ & $\begin{array}{c}0.193 * * * \\
(0.027)\end{array}$ & $\begin{array}{c}0.267 * * * \\
(0.046)\end{array}$ \\
\hline Higher degree/Degree & $\begin{array}{c}-0.339 * * * \\
(0.045)\end{array}$ & $\begin{array}{c}-0.283^{* * *} \\
(0.053)\end{array}$ & $\begin{array}{c}-0.473 * * * \\
(0.093)\end{array}$ & & & \\
\hline HND or equivalent & $\begin{array}{c}-0.213 * * * \\
(0.049)\end{array}$ & $\begin{array}{c}-0.180 * * * \\
(0.059)\end{array}$ & $\begin{array}{c}-0.242 * * \\
(0.099)\end{array}$ & & & \\
\hline A-level & $\begin{array}{c}-0.164 * * * \\
(0.038)\end{array}$ & $\begin{array}{c}-0.108 * * \\
(0.044)\end{array}$ & $\begin{array}{c}-0.242 * * * \\
(0.088)\end{array}$ & & & \\
\hline GCSE/O-level & $\begin{array}{c}-0.094 * * * \\
(0.035)\end{array}$ & $\begin{array}{l}-0.057 \\
(0.038)\end{array}$ & $\begin{array}{l}-0.138 \\
(0.087)\end{array}$ & & & \\
\hline CSE & $\begin{array}{l}-0.050 \\
(0.049)\end{array}$ & $\begin{array}{c}0.008 \\
(0.059)\end{array}$ & $\begin{array}{l}-0.109 \\
(0.103)\end{array}$ & & & \\
\hline Health over last 12 months 'excellent' & $\begin{array}{c}0.269 * * * \\
(0.017)\end{array}$ & $\begin{array}{c}0.275^{* * *} * \\
(0.021)\end{array}$ & $\begin{array}{c}0.242^{* * * *} \\
(0.029)\end{array}$ & $\begin{array}{c}0.137 * * * \\
(0.015)\end{array}$ & $\begin{array}{c}0.123 * * * \\
(0.018)\end{array}$ & $\begin{array}{c}0.174 * * * \\
(0.031)\end{array}$ \\
\hline Married & $\begin{array}{c}0.157 * * * \\
(0.026)\end{array}$ & $\begin{array}{c}0.174 * * * \\
(0.031)\end{array}$ & $\begin{array}{c}0.097 * * \\
(0.043)\end{array}$ & $\begin{array}{c}0.069 * * * \\
(0.026)\end{array}$ & $\begin{array}{c}0.074 * * \\
(0.031)\end{array}$ & $\begin{array}{c}0.035 \\
(0.051)\end{array}$ \\
\hline Living as a couple & $\begin{array}{l}0.046^{*} \\
(0.028)\end{array}$ & $\begin{array}{l}0.071 * \\
(0.042)\end{array}$ & $\begin{array}{l}-0.002 \\
(0.036)\end{array}$ & $\begin{array}{l}-0.021 \\
(0.026)\end{array}$ & $\begin{array}{l}-0.039 \\
(0.036)\end{array}$ & $\begin{array}{l}-0.021 \\
(0.040)\end{array}$ \\
\hline Number of dependent children & $\begin{array}{c}0.058^{* * *} \\
(0.011)\end{array}$ & $\begin{array}{c}0.059 * * * \\
(0.013)\end{array}$ & $\begin{array}{c}0.090 * * * \\
(0.021)\end{array}$ & $\begin{array}{c}0.047 * * * \\
(0.011)\end{array}$ & $\begin{array}{c}0.047 * * * \\
(0.012)\end{array}$ & $\begin{array}{c}0.039 \\
(0.028)\end{array}$ \\
\hline Constant & $\begin{array}{c}6.026 * * * \\
(0.152) \\
\end{array}$ & $\begin{array}{c}5.851 * * * \\
(0.250) \\
\end{array}$ & $\begin{array}{c}5.577 * * * \\
(0.387) \\
\end{array}$ & $\begin{array}{c}5.251 * * * \\
(0.204) \\
\end{array}$ & $\begin{array}{c}5.282^{* * * *} \\
(0.218)\end{array}$ & $\begin{array}{c}4.118^{* * * *} \\
(0.387)\end{array}$ \\
\hline Number of Observations & 45,537 & 33,420 & 12,117 & 45,537 & 33,420 & 12,117 \\
\hline Number of Individuals & & & & 7,690 & 4,815 & 2,875 \\
\hline P-value (Ho: $\left.\alpha_{i}=0\right)$ & & & & 0.00 & 0.00 & 0.00 \\
\hline $\begin{array}{l}\text { Notes: (1) The linear regressions also inclu } \\
\text { workplace (>1000), age, age-squared, a set of } \\
\text { on person identifier. (2) The fixed-effects line } \\
\text { survey. (3) Standard errors are in parenthesis. }\end{array}$ & $<<0.01, * *$ & $\begin{array}{l}\text { and time } \\
\text { include } \\
.05, * \mathrm{p}<\end{array}$ & of region & $\begin{array}{l}\text { of survey } \\
\text { immies, }\end{array}$ & $\begin{array}{l}\text { indard e } \\
\text { time du }\end{array}$ & $\begin{array}{l}\text { mployees } \\
\text { are clustere } \\
\text { for year o }\end{array}$ \\
\hline
\end{tabular}


Table 5: Job Satisfaction - Interaction Effects

\begin{tabular}{|c|c|c|c|c|c|c|}
\hline \multirow[b]{2}{*}{ Variable } & \multicolumn{3}{|c|}{ Panel A: Education interactions } & \multicolumn{3}{|c|}{ Panel B: Job interactions } \\
\hline & All & $\begin{array}{c}\text { Born before } \\
1970 \\
\end{array}$ & $\begin{array}{l}\text { Born in or } \\
\text { after } 1970 \\
\end{array}$ & All & $\begin{array}{c}\text { Born before } \\
1970 \\
\end{array}$ & $\begin{array}{l}\text { Born in or } \\
\text { after } 1970\end{array}$ \\
\hline Part-time*Born in or after 1970 & $\begin{array}{l}-0.071^{*} \\
(0.042)\end{array}$ & & & $\begin{array}{c}-0.091 * * \\
(0.041)\end{array}$ & & \\
\hline Ln(real hourly wage) & $\begin{array}{c}0.003 * * \\
(0.002)\end{array}$ & $\begin{array}{c}0.002 \\
(0.002)\end{array}$ & $\begin{array}{c}0.012 * * \\
(0.005)\end{array}$ & $\begin{array}{c}0.005^{* *} \\
(0.002)\end{array}$ & $\begin{array}{c}0.003 \\
(0.002)\end{array}$ & $\begin{array}{c}0.020 * * * \\
(0.007)\end{array}$ \\
\hline Health over last 12 months 'excellent' & $\begin{array}{c}0.137 * * * \\
(0.015)\end{array}$ & $\begin{array}{c}0.123 * * * \\
(0.018)\end{array}$ & $\begin{array}{c}0.175 * * * \\
(0.031)\end{array}$ & $\begin{array}{c}0.136^{* * * *} \\
(0.015)\end{array}$ & $\begin{array}{c}0.123 * * * \\
(0.018)\end{array}$ & $\begin{array}{c}0.173 * * * \\
(0.031)\end{array}$ \\
\hline Married & $\begin{array}{c}0.070 * * * \\
(0.026)\end{array}$ & $\begin{array}{c}0.074 * * \\
(0.031)\end{array}$ & $\begin{array}{c}0.038 \\
(0.051)\end{array}$ & $\begin{array}{c}0.070 * * * \\
(0.026)\end{array}$ & $\begin{array}{c}0.075^{* *} \\
(0.031)\end{array}$ & $\begin{array}{c}0.037 \\
(0.051)\end{array}$ \\
\hline Living as a couple & $\begin{array}{l}-0.021 \\
(0.026)\end{array}$ & $\begin{array}{l}-0.039 \\
(0.036)\end{array}$ & $\begin{array}{l}-0.021 \\
(0.040)\end{array}$ & $\begin{array}{l}-0.022 \\
(0.026)\end{array}$ & $\begin{array}{l}-0.038 \\
(0.036)\end{array}$ & $\begin{array}{l}-0.022 \\
(0.040)\end{array}$ \\
\hline Number of dependent children & $\begin{array}{c}0.049 * * * \\
(0.011)\end{array}$ & $\begin{array}{c}0.049 * * * \\
(0.012)\end{array}$ & $\begin{array}{c}0.038 \\
(0.028)\end{array}$ & $\begin{array}{c}0.048 * * * \\
(0.011)\end{array}$ & $\begin{array}{c}0.047 * * * \\
(0.012)\end{array}$ & $\begin{array}{l}0.047 * \\
(0.028)\end{array}$ \\
\hline Part-time*A-level & $\begin{array}{l}-0.054 \\
(0.057)\end{array}$ & $\begin{array}{l}-0.098 \\
(0.062)\end{array}$ & $\begin{array}{c}0.303 \\
(0.199)\end{array}$ & & & \\
\hline Part-time*GCSE/O-level & $\begin{array}{c}-0.112 * * \\
(0.050)\end{array}$ & $\begin{array}{c}-0.128 * * \\
(0.052)\end{array}$ & $\begin{array}{c}0.197 \\
(0.197)\end{array}$ & & & \\
\hline Part-time*CSE & $\begin{array}{c}-0.234 * * * \\
(0.077)\end{array}$ & $\begin{array}{c}-0.269 * * * \\
(0.088)\end{array}$ & $\begin{array}{c}0.100 \\
(0.220)\end{array}$ & & & \\
\hline $\begin{array}{l}\text { Job Interactions: } \\
\text { Part-time*Occupational ranking } \\
\text { (Hope-Goldthorpe scale) }\end{array}$ & & & & $\begin{array}{l}-0.0002 \\
(0.001)\end{array}$ & $\begin{array}{c}0.001 \\
(0.001)\end{array}$ & $\begin{array}{l}-0.002 \\
(0.003)\end{array}$ \\
\hline Part-time*Ln(real hourly wage) & & & & $\begin{array}{l}-0.002 \\
(0.003)\end{array}$ & $\begin{array}{l}-0.001 \\
(0.003)\end{array}$ & $\begin{array}{l}-0.011 \\
(0.009)\end{array}$ \\
\hline $\begin{array}{l}\text { Part-time*Pay includes annual } \\
\text { increments }\end{array}$ & & & & $\begin{array}{c}-0.123^{* * *} * \\
(0.028)\end{array}$ & $\begin{array}{c}-0.100 * * * \\
(0.032)\end{array}$ & $\begin{array}{c}-0.206 * * * \\
(0.067)\end{array}$ \\
\hline $\begin{array}{l}\text { Part-time*Employed in the public } \\
\text { sector }\end{array}$ & & & & -0.038 & -0.038 & 0.005 \\
\hline
\end{tabular}




\begin{tabular}{|l|ccc|ccc|} 
& & & $(0.034)$ & $(0.039)$ & $(0.080)$ \\
Constant & $5.254^{* * *}$ & $5.285^{* * *}$ & $4.130^{* * *}$ & $5.194 * * *$ & $5.241^{* * *}$ & $4.036^{* * *}$ \\
& $(0.204)$ & $(0.218)$ & $(0.387)$ & $(0.205)$ & $(0.219)$ & $(0.388)$ \\
\hline Number of Observations & 45,537 & 33,420 & 12,117 & 45,537 & 33,420 & 12,117 \\
Number of Individuals & 7,690 & 4,815 & 2,875 & 7,690 & 4,815 & 2,875 \\
\hline Nuts
\end{tabular}

Notes: All regressions include a set of regional dummies, and time dummies for year of survey. Standard errors are in parenthesis. $* * * \mathrm{p}<0.01, * * \mathrm{p}<0.05, * \mathrm{p}<0.1$ 
Table 6: Job Satisfaction - The Role of Family

\begin{tabular}{|c|c|c|c|c|c|c|c|c|}
\hline \multirow[b]{2}{*}{ Variable } & \multicolumn{4}{|c|}{ Panel A } & \multicolumn{4}{|c|}{ Panel B: with child interaction } \\
\hline & $\begin{array}{c}\text { Born } \\
\text { before } \\
\text { 1970: } \\
\text { Single }\end{array}$ & $\begin{array}{c}\text { Born } \\
\text { before } \\
\text { 1970: } \\
\text { Couple }\end{array}$ & $\begin{array}{c}\text { Born in } \\
\text { or after } \\
\text { 1970: } \\
\text { Single }\end{array}$ & $\begin{array}{c}\text { Born in } \\
\text { or after } \\
\text { 1970: } \\
\text { Couple }\end{array}$ & $\begin{array}{c}\text { Born } \\
\text { before } \\
\text { 1970: } \\
\text { Single }\end{array}$ & $\begin{array}{c}\text { Born } \\
\text { before } \\
\text { 1970: } \\
\text { Couple }\end{array}$ & $\begin{array}{c}\text { Born in } \\
\text { or after } \\
\text { 1970: } \\
\text { Single }\end{array}$ & $\begin{array}{c}\text { Born in } \\
\text { or after } \\
\text { 1970: } \\
\text { Couple }\end{array}$ \\
\hline Employed part-time & $\begin{array}{l}0.203 * * * \\
(0.061)\end{array}$ & $\begin{array}{c}0.143 * * * \\
(0.023)\end{array}$ & $\begin{array}{c}0.074 \\
(0.073)\end{array}$ & $\begin{array}{l}0.090 * \\
(0.054)\end{array}$ & $\begin{array}{l}0.227 * * * \\
(0.073)\end{array}$ & $\begin{array}{l}0.202 * * * \\
(0.030)\end{array}$ & $\begin{array}{c}0.114 \\
(0.090)\end{array}$ & $\begin{array}{l}-0.003 \\
(0.079)\end{array}$ \\
\hline $\begin{array}{l}\text { Occupational ranking (Hope- } \\
\text { Goldthorpe scale) }\end{array}$ & $\begin{array}{c}0.006 * * * \\
(0.002)\end{array}$ & $\begin{array}{c}0.004 * * * \\
(0.001)\end{array}$ & $\begin{array}{c}0.007 * * * \\
(0.002)\end{array}$ & $\begin{array}{c}0.005 * * * \\
(0.002)\end{array}$ & $\begin{array}{c}0.006 * * * \\
(0.002)\end{array}$ & $\begin{array}{c}0.003 * * * \\
(0.001)\end{array}$ & $\begin{array}{c}0.007 * * * \\
(0.002)\end{array}$ & $\begin{array}{c}0.005 * * * \\
(0.002)\end{array}$ \\
\hline Ln(real hourly wage) & $\begin{array}{l}0.015^{* *} \\
(0.006)\end{array}$ & $\begin{array}{c}0.000 \\
(0.002)\end{array}$ & $\begin{array}{l}0.031 * * * \\
(0.010)\end{array}$ & $\begin{array}{c}0.006 \\
(0.007)\end{array}$ & $\begin{array}{l}0.015 * * \\
(0.006)\end{array}$ & $\begin{array}{l}-0.000 \\
(0.002)\end{array}$ & $\begin{array}{l}0.031 * * * \\
(0.010)\end{array}$ & $\begin{array}{c}0.007 \\
(0.007)\end{array}$ \\
\hline Pay includes annual increments & $\begin{array}{l}0.175 * * * \\
(0.040)\end{array}$ & $\begin{array}{l}0.112 * * * \\
(0.018)\end{array}$ & $\begin{array}{l}0.206 * * * \\
(0.049)\end{array}$ & $\begin{array}{c}0.164 * * * \\
(0.040)\end{array}$ & $\begin{array}{c}0.175^{* * * *} \\
(0.040)\end{array}$ & $\begin{array}{c}0.112 * * * \\
(0.018)\end{array}$ & $\begin{array}{l}0.206 * * * \\
(0.049)\end{array}$ & $\begin{array}{c}0.165 * * * \\
(0.040)\end{array}$ \\
\hline Employed in the public sector & $\begin{array}{l}0.184 * * * \\
(0.068)\end{array}$ & $\begin{array}{l}0.206 * * * \\
(0.030)\end{array}$ & $\begin{array}{l}0.288 * * * \\
(0.076)\end{array}$ & $\begin{array}{l}0.251 * * * \\
(0.064)\end{array}$ & $\begin{array}{c}0.185^{* * * *} \\
(0.068)\end{array}$ & $\begin{array}{l}0.205 * * * \\
(0.030)\end{array}$ & $\begin{array}{l}0.289 * * * \\
(0.076)\end{array}$ & $\begin{array}{l}0.252 * * * \\
(0.064)\end{array}$ \\
\hline $\begin{array}{l}\text { Health over last } 12 \text { months } \\
\text { 'excellent' }\end{array}$ & $\begin{array}{c}0.197 * * * \\
(0.042)\end{array}$ & $\begin{array}{l}0.099 * * * \\
(0.020)\end{array}$ & $\begin{array}{c}0.141 * * * \\
(0.052)\end{array}$ & $\begin{array}{c}0.182 * * * \\
(0.041)\end{array}$ & $\begin{array}{c}0.197 * * * \\
(0.042)\end{array}$ & $\begin{array}{c}0.099 * * * \\
(0.020)\end{array}$ & $\begin{array}{c}0.140 * * * \\
(0.052)\end{array}$ & $\begin{array}{c}0.180 * * * \\
(0.041)\end{array}$ \\
\hline Number of dependent children & $\begin{array}{c}0.055 \\
(0.040)\end{array}$ & $\begin{array}{c}0.043 * * * \\
(0.013)\end{array}$ & $\begin{array}{c}0.048 \\
(0.059)\end{array}$ & $\begin{array}{c}0.040 \\
(0.039)\end{array}$ & $\begin{array}{c}0.067 \\
(0.045)\end{array}$ & $\begin{array}{l}0.071 * * * \\
(0.016)\end{array}$ & $\begin{array}{c}0.065 \\
(0.063)\end{array}$ & $\begin{array}{c}0.012 \\
(0.042)\end{array}$ \\
\hline $\begin{array}{l}\text { Part-time*Number of dependent } \\
\text { children }\end{array}$ & & & & & $\begin{array}{l}-0.036 \\
(0.060)\end{array}$ & $\begin{array}{c}-0.061 * * * \\
(0.020)\end{array}$ & $\begin{array}{l}-0.062 \\
(0.083)\end{array}$ & $\begin{array}{c}0.082 \\
(0.052)\end{array}$ \\
\hline Constant & $\begin{array}{c}5.063 * * * \\
(0.932) \\
\end{array}$ & $\begin{array}{c}5.569 * * * \\
(0.253) \\
\end{array}$ & $\begin{array}{c}4.996 * * * \\
(0.574) \\
\end{array}$ & $\begin{array}{c}5.082 * * * \\
(1.193) \\
\end{array}$ & $\begin{array}{c}5.049 * * * \\
(0.933)\end{array}$ & $\begin{array}{c}5.323 * * * \\
(0.270)\end{array}$ & $\begin{array}{c}4.532 * * * \\
(0.690)\end{array}$ & $\begin{array}{c}5.172 * * * \\
(1.194)\end{array}$ \\
\hline Number of Observations & 7,262 & 26,158 & 5,350 & 6,767 & 7,262 & 26,158 & 5,350 & 6,767 \\
\hline Number of Individuals & 1,571 & 3,973 & 1,853 & 1,684 & 1,571 & 3,973 & 1,853 & 1,684 \\
\hline
\end{tabular}

Notes: All regressions include a set of regional dummies, and time dummies for year of survey. Standard errors are in parenthesis. $* * * \mathrm{p}<0.01, * * \mathrm{p}<0.05, * \mathrm{p}<0.1$ 
Table 7: Job Satisfaction - Sensitivity Analysis

\begin{tabular}{|c|c|c|c|c|c|c|}
\hline \multirow[b]{2}{*}{ Variable } & \multicolumn{3}{|c|}{ Panel A: Pooled Ordered Logit } & \multicolumn{3}{|c|}{ Panel B: Fixed Effects Logit } \\
\hline & All & $\begin{array}{c}\text { Born before } \\
1970\end{array}$ & $\begin{array}{l}\text { Born in or } \\
\text { after } 1970\end{array}$ & All & $\begin{array}{c}\text { Born before } \\
1970\end{array}$ & $\begin{array}{l}\text { Born in or } \\
\text { after } 1970\end{array}$ \\
\hline Employed part-time & $\begin{array}{l}0.370^{* * *} \\
(0.038)\end{array}$ & $\begin{array}{c}0.356 * * * \\
(0.039)\end{array}$ & $\begin{array}{c}0.177 * * * \\
(0.065)\end{array}$ & $\begin{array}{c}0.324 * * * \\
(0.050)\end{array}$ & $\begin{array}{c}0.321 * * * \\
(0.050)\end{array}$ & $\begin{array}{l}0.207 * * \\
(0.085)\end{array}$ \\
\hline Part-time*Born in or after 1970 & $\begin{array}{c}-0.153 * * \\
(0.061)\end{array}$ & & & $\begin{array}{l}-0.124 \\
(0.091)\end{array}$ & & \\
\hline $\begin{array}{l}\text { Occupational ranking (Hope- } \\
\text { Goldthorpe scale) }\end{array}$ & $\begin{array}{c}0.001 \\
(0.001)\end{array}$ & $\begin{array}{l}-0.001 \\
(0.001)\end{array}$ & $\begin{array}{c}0.007 * * * \\
(0.002)\end{array}$ & $\begin{array}{c}0.008 * * * \\
(0.002)\end{array}$ & $\begin{array}{c}0.007 * * * \\
(0.002)\end{array}$ & $\begin{array}{c}0.007 * * * \\
(0.003)\end{array}$ \\
\hline Ln(real hourly wage) & $\begin{array}{c}0.006 \\
(0.004)\end{array}$ & $\begin{array}{c}0.005 \\
(0.004)\end{array}$ & $\begin{array}{c}0.026 * * * \\
(0.008)\end{array}$ & $\begin{array}{c}0.012 * * \\
(0.005)\end{array}$ & $\begin{array}{c}0.007 \\
(0.005)\end{array}$ & $\begin{array}{c}0.045 * * * \\
(0.014)\end{array}$ \\
\hline Pay includes annual increments & $\begin{array}{c}0.221 * * * \\
(0.027)\end{array}$ & $\begin{array}{c}0.206 * * * \\
(0.033)\end{array}$ & $\begin{array}{c}0.233 * * * \\
(0.046)\end{array}$ & $\begin{array}{c}0.231 * * * \\
(0.033)\end{array}$ & $\begin{array}{c}0.237 * * * \\
(0.039)\end{array}$ & $\begin{array}{c}0.209 * * * \\
(0.062)\end{array}$ \\
\hline Employed in the public sector & $\begin{array}{c}0.291 * * * \\
(0.038)\end{array}$ & $\begin{array}{c}0.265 * * * \\
(0.045)\end{array}$ & $\begin{array}{c}0.407 * * * \\
(0.064)\end{array}$ & $\begin{array}{c}0.449 * * * \\
(0.052)\end{array}$ & $\begin{array}{c}0.383 * * * \\
(0.062)\end{array}$ & $\begin{array}{c}0.610 * * * \\
(0.096)\end{array}$ \\
\hline Higher degree/Degree & $\begin{array}{c}-0.613 * * * \\
(0.070)\end{array}$ & $\begin{array}{c}-0.537 * * * \\
(0.081)\end{array}$ & $\begin{array}{c}-0.791 * * * \\
(0.165)\end{array}$ & & & \\
\hline HND or equivalent & $\begin{array}{c}-0.449 * * * \\
(0.077)\end{array}$ & $\begin{array}{c}-0.392 * * * \\
(0.091)\end{array}$ & $\begin{array}{c}-0.498 * * * \\
(0.175)\end{array}$ & & & \\
\hline A-level & $\begin{array}{c}-0.360 * * * \\
(0.062)\end{array}$ & $\begin{array}{c}-0.263 * * * \\
(0.070)\end{array}$ & $\begin{array}{c}-0.488 * * * \\
(0.162)\end{array}$ & & & \\
\hline GCSE/O-level & $\begin{array}{c}-0.248 * * * \\
(0.058)\end{array}$ & $\begin{array}{c}-0.180 * * * \\
(0.063)\end{array}$ & $\begin{array}{c}-0.332 * * \\
(0.160)\end{array}$ & & & \\
\hline CSE & $\begin{array}{l}-0.160^{*} \\
(0.085)\end{array}$ & $\begin{array}{l}-0.065 \\
(0.102)\end{array}$ & $\begin{array}{l}-0.241 \\
(0.190)\end{array}$ & & & \\
\hline $\begin{array}{l}\text { Health over last } 12 \text { months } \\
\text { 'excellent' }\end{array}$ & $\begin{array}{c}0.454 * * * \\
(0.028)\end{array}$ & $\begin{array}{c}0.467 * * * \\
(0.035)\end{array}$ & $\begin{array}{c}0.403 * * * \\
(0.046)\end{array}$ & $\begin{array}{c}0.271 * * * \\
(0.036)\end{array}$ & $\begin{array}{c}0.264 * * * \\
(0.042)\end{array}$ & $\begin{array}{c}0.289 * * * \\
(0.067)\end{array}$ \\
\hline Married & $\begin{array}{c}0.222 * * * \\
(0.039)\end{array}$ & $\begin{array}{c}0.246 * * * \\
(0.046)\end{array}$ & $\begin{array}{c}0.141^{* *} \\
(0.068)\end{array}$ & $\begin{array}{l}0.097^{*} \\
(0.058)\end{array}$ & $\begin{array}{c}0.142 * * \\
(0.072)\end{array}$ & $\begin{array}{l}-0.057 \\
(0.106)\end{array}$ \\
\hline Living as a couple & $\begin{array}{c}0.093 * * \\
(0.041)\end{array}$ & $\begin{array}{c}0.136^{* *} \\
(0.062)\end{array}$ & $\begin{array}{c}0.020 \\
(0.055)\end{array}$ & $\begin{array}{c}0.010 \\
(0.057)\end{array}$ & $\begin{array}{l}-0.029 \\
(0.084)\end{array}$ & $\begin{array}{l}-0.001 \\
(0.082)\end{array}$ \\
\hline Number of dependent children & $\begin{array}{c}0.088^{* * * *} \\
(0.018)\end{array}$ & $\begin{array}{c}0.088^{* * *} \\
(0.021)\end{array}$ & $\begin{array}{c}0.150 * * * \\
(0.035)\end{array}$ & $0.092 * * *$ & $0.094 * * *$ & 0.086 \\
\hline $\begin{array}{l}\text { Number of Observations } \\
\text { Number of Individuals } \\
\text { Log-likelihood }\end{array}$ & 45,537 & 33,420 & 12,117 & $\begin{array}{c}34,366 \\
4,080 \\
-14,335\end{array}$ & $\begin{array}{c}25,547 \\
2,732 \\
-10,684\end{array}$ & $\begin{array}{r}8,819 \\
1,348 \\
-3,630\end{array}$ \\
\hline $\begin{array}{l}\text { Log-likelihood } \\
\text { Notes: (1) Ordered logit regr } \\
\text { workplace }(>1000) \text {, age, age-sc } \\
\text { person identifier. (2) Fixed-eff } \\
\text { auxiliary parameters are not rep }\end{array}$ & $\begin{array}{l}-64,870 \\
\text { s include } \\
\text { l, regional } \\
\text { near regre } \\
\text { (3) Stand }\end{array}$ & $\begin{array}{l}-47,363 \\
\text { rols for un } \\
\text { mies and ti } \\
\text { s include a } \\
\text { rors are in } \mathrm{p}\end{array}$ & $\begin{array}{l}-17,377 \\
\text { immies ftaf ass } \\
\text { f regional } \\
\text { hesis. } * * *\end{array}$ & $\begin{array}{l}\text { nies, and } \\
1, * * p<0 \text {. }\end{array}$ & $\begin{array}{l}-10,684 \\
\text { andard error } \\
\text { dummies fo } \\
\mathrm{p}<0.1\end{array}$ & $\begin{array}{l}-3,630 \\
\text { mployees a } \\
\text { clustered or } \\
\text { ar of survey }\end{array}$ \\
\hline
\end{tabular}


Table 8: Job Satisfaction - Age Range

\begin{tabular}{|c|c|c|c|c|}
\hline \multirow{3}{*}{ Variable } & $(1)$ & $(2)$ & (3) & $(4)$ \\
\hline & $\begin{array}{c}\text { Born } \\
\text { before } \\
1970 \\
\end{array}$ & \multicolumn{3}{|c|}{ Born in or after 1970} \\
\hline & Age $<55$ & Age $>=23$ & Age $>=23$ & Age $>=23$ \\
\hline & & \multicolumn{3}{|c|}{$\begin{array}{r}\text { Child interaction } \\
\text { Couple }\end{array}$} \\
\hline Employed part-time & $\begin{array}{c}0.118 * * * \\
(0.023)\end{array}$ & $\begin{array}{c}0.079 \\
(0.050)\end{array}$ & $\begin{array}{l}-0.007 \\
(0.073)\end{array}$ & $\begin{array}{l}-0.092 \\
(0.089)\end{array}$ \\
\hline Occupational ranking (Hope-Goldthorpe scale) & $\begin{array}{c}0.005 * * * \\
(0.001)\end{array}$ & $\begin{array}{l}0.005 * * * \\
(0.002)\end{array}$ & $\begin{array}{l}0.005 * * * \\
(0.002)\end{array}$ & $\begin{array}{c}0.006 * * * \\
(0.002)\end{array}$ \\
\hline Ln(real hourly wage) & $\begin{array}{c}0.002 \\
(0.002)\end{array}$ & $\begin{array}{l}0.011 * \\
(0.006)\end{array}$ & $\begin{array}{l}0.011 * \\
(0.006)\end{array}$ & $\begin{array}{c}0.008 \\
(0.007)\end{array}$ \\
\hline Pay includes annual increments & $\begin{array}{l}0.116^{* * * *} \\
(0.018)\end{array}$ & $\begin{array}{c}0.156^{* * * *} \\
(0.035)\end{array}$ & $\begin{array}{c}0.156 * * * \\
(0.035)\end{array}$ & $\begin{array}{c}0.195 * * * \\
(0.043)\end{array}$ \\
\hline Employed in the public sector & $\begin{array}{c}0.209 * * * \\
(0.029)\end{array}$ & $\begin{array}{c}0.274 * * * \\
(0.057)\end{array}$ & $\begin{array}{c}0.275^{* * *} \\
(0.057)\end{array}$ & $\begin{array}{c}0.246 * * * \\
(0.071)\end{array}$ \\
\hline Health over last 12 months 'excellent' & $\begin{array}{l}0.120 * * * \\
(0.019)\end{array}$ & $\begin{array}{c}0.143 * * * \\
(0.036)\end{array}$ & $\begin{array}{l}0.142 * * * \\
(0.036)\end{array}$ & $\begin{array}{c}0.141 * * * \\
(0.044)\end{array}$ \\
\hline Married & $\begin{array}{c}0.067 * * \\
(0.033)\end{array}$ & $\begin{array}{c}0.055 \\
(0.060)\end{array}$ & $\begin{array}{c}0.058 \\
(0.060)\end{array}$ & \\
\hline Living as a couple & $\begin{array}{l}-0.047 \\
(0.037)\end{array}$ & $\begin{array}{c}0.012 \\
(0.050)\end{array}$ & $\begin{array}{c}0.011 \\
(0.050)\end{array}$ & \\
\hline Number of dependent children & $\begin{array}{c}0.053 * * * \\
(0.012)\end{array}$ & $\begin{array}{c}0.017 \\
(0.036)\end{array}$ & $\begin{array}{l}-0.009 \\
(0.039)\end{array}$ & $\begin{array}{c}0.006 \\
(0.045)\end{array}$ \\
\hline Part-time*Number of dependent children & & & $\begin{array}{c}0.077 \\
(0.048)\end{array}$ & $\begin{array}{c}0.117 * * \\
(0.056)\end{array}$ \\
\hline Constant & $\begin{array}{c}5.144 * * * \\
(0.206)\end{array}$ & $\begin{array}{c}3.841 * * * \\
(0.552) \\
\end{array}$ & $\begin{array}{c}3.858 * * * \\
(0.552) \\
\end{array}$ & $\begin{array}{c}5.029 * * * \\
(0.755)\end{array}$ \\
\hline Number of Observations & 28,749 & 8,492 & 8,492 & 5,796 \\
\hline Number of Individuals & 4,397 & 2,024 & 2,024 & 1,438 \\
\hline
\end{tabular}


Table 9: Job Satisfaction - Pathways and Adaptation

\begin{tabular}{|c|c|c|c|c|c|c|}
\hline \multirow[b]{2}{*}{ Variable } & \multicolumn{3}{|c|}{ Panel A } & \multicolumn{3}{|c|}{ Panel B } \\
\hline & All & $\begin{array}{c}\text { Born } \\
\text { before } \\
1970 \\
\end{array}$ & $\begin{array}{l}\text { Born in or } \\
\text { after } 1970\end{array}$ & All & $\begin{array}{c}\text { Born } \\
\text { before } \\
1970 \\
\end{array}$ & $\begin{array}{l}\text { Born in or } \\
\text { after } 1970\end{array}$ \\
\hline Pathways: & & & & & & \\
\hline Part-time to part-time & $\begin{array}{c}0.132 * * * \\
(0.023)\end{array}$ & $\begin{array}{c}0.149 * * * \\
(0.025)\end{array}$ & $\begin{array}{c}0.068 \\
(0.054)\end{array}$ & & & \\
\hline Full-time to part-time & $\begin{array}{c}0.111 * * * \\
(0.032)\end{array}$ & $\begin{array}{c}0.150 * * * \\
(0.036)\end{array}$ & $\begin{array}{l}-0.006 \\
(0.069)\end{array}$ & & & \\
\hline $\begin{array}{l}\text { Self-employment to part- } \\
\text { time }\end{array}$ & $\begin{array}{c}0.240 * * \\
(0.120)\end{array}$ & $\begin{array}{c}0.287 * * \\
(0.127)\end{array}$ & $\begin{array}{l}-0.010 \\
(0.333)\end{array}$ & & & \\
\hline Unemployment to part-time & $\begin{array}{c}0.392 * * * \\
(0.084)\end{array}$ & $\begin{array}{c}0.378 * * * \\
(0.096)\end{array}$ & $\begin{array}{l}0.440 * * \\
(0.173)\end{array}$ & & & \\
\hline Maternity to part-time & $\begin{array}{c}0.175 * * * \\
(0.066)\end{array}$ & $\begin{array}{c}0.313 * * * \\
(0.087)\end{array}$ & $\begin{array}{l}-0.027 \\
(0.105)\end{array}$ & & & \\
\hline Family care to part-time & $\begin{array}{c}0.311^{* * *} \\
(0.048)\end{array}$ & $\begin{array}{c}0.339 * * * \\
(0.055)\end{array}$ & $\begin{array}{l}0.239 * * \\
(0.100)\end{array}$ & & & \\
\hline Education to part-time & $\begin{array}{c}0.063 \\
(0.095)\end{array}$ & $\begin{array}{l}-0.232 \\
(0.224)\end{array}$ & $\begin{array}{c}0.130 \\
(0.112)\end{array}$ & & & \\
\hline Other to part-time & $\begin{array}{c}0.391 * * * \\
(0.106)\end{array}$ & $\begin{array}{c}0.450 * * * \\
(0.116)\end{array}$ & $\begin{array}{c}0.160 \\
(0.257)\end{array}$ & & & \\
\hline Adaptation: & & & & & & \\
\hline Part-time for $0-1$ years & & & & $\begin{array}{c}0.192 * * * \\
(0.027)\end{array}$ & $\begin{array}{c}0.224 * * * \\
(0.031)\end{array}$ & $\begin{array}{l}0.112 * * \\
(0.053)\end{array}$ \\
\hline Part-time for 1-2 years & & & & $\begin{array}{c}0.123^{* * *} * \\
(0.031)\end{array}$ & $\begin{array}{c}0.134 * * * \\
(0.035)\end{array}$ & $\begin{array}{c}0.086 \\
(0.067)\end{array}$ \\
\hline Part-time for 2 years or more & & & & $\begin{array}{c}0.104 * * * \\
(0.026)\end{array}$ & $\begin{array}{c}0.112 * * * \\
(0.028)\end{array}$ & $\begin{array}{c}0.076 \\
(0.068)\end{array}$ \\
\hline Number of Observations & 40,548 & 29,900 & 10,648 & 35,532 & 26,309 & 9,223 \\
\hline Number of Individuals & 6,693 & 4,292 & 2,401 & 5,962 & 3,880 & 2,082 \\
\hline
\end{tabular}

